\title{
CSR AS A MARKETING COMMUNICATION TOOL FOR COMPANIES IN THE FINANCIAL SERVICES SECTOR
}

\section{MARIUSZ WOŹNIAKOWSKI}

University of Lodz, POLAND

e-mail: m.wozniakowski@uni.lodz.pl

\section{RECEIVED}

ACCEPTED

JEL

CLASSIFICATION

KEYWORDS

ABSTRACT
16 August 2017

15 December 2017

M14, M31

CSR, corporate social responsibility, marketing communication, public relations

The article focuses on the identification of the concept and the role that corporate social responsibility may play in marketing communication of the companies of the financial services sector. The reflections start with an overview of the essence of corporate social responsibility, and move on to illustrate the relations between CSR and marketing communication. The author's own research is the key part. For the purposes of this publication, an analysis of the website contents of the financial sector companies (operating on the Polish market) was conducted. The companies come from the compilation "Lista 500" of the largest Polish enterprises, published by „Rzeczpospolita” daily in April 2017 (the entities whose PKD classification - Polish Statistical Classification of Economic Activities - was specified predominantly as: financial and insurance activity, were selected).

The article describes how the listed entities communicate their CSR activities via the company website. It illustrates selected areas of engagement ( 5 were highlighted) as well as the relationship between activities of pro-social nature and the activity in the area of marketing communication in a given industry. Moreover, it emphasises the differences in the mode of communication and the area of employing CSR activities between two dominating groups of entities on the financial market - banks and insurance companies.

\section{Introduction}

Today's strongly competitive market presents companies with increasingly more challenges related to gaining and retaining clients. In order to stand out and project a good image, companies have started considering social interests, relations with various groups of stakeholders or natural environment protection at an early stage of 
developing strategies, which translates to active participation in the area of corporate social responsibility (CSR) as well as (indirectly) to the way these activities are communicated to the surroundings (Woźniakowski, 2015).

Currently, companies' participation in corporate social responsibility is largely unrelated to strictly philanthropic activities of an entity. CSR has become the right approach required by most stakeholders towards the society in which the activity is conducted. These days, most marketing measures are based on interpersonal relations, which entails human emotions. This fact encourages marketers to make the most of pro-social activities. Therefore, supporting activities from the area of CSR may also be aimed at the development of good relations with the environment and the creation of a company's positive image or its improvement (Gontarczyk, 2003) This in turn is used in PR activities. Thus, it can be assumed that the CSR policies, including the financial sector entities, is primarily dependent on financial results and the role of the CSR activities in the hierarchy of communication strategies of these units (Woźniakowski, 2015).

This article will focus on how the companies in the financial services sector communicate their CSR activities via their company websites. It will discuss selected areas of engagement and the relationship between pro-social activity and marketing communication activity, particularly in the area of these entities' public relations.

\section{The Essence of Copporate Social Responsibility}

The CSR research offers rich empirical and theoretical materials that explain the origin and development of this concept. CSR emerged in the USA in response to certain institutional gaps (Carroll, 1999), which resulted in a shortage of goods and public services rendered by the government for the benefit of its citizens. Initially, the concept of social responsibility translated to various private persons' and companies' investments into medicare, education, libraries or elementary systems of employee protection, offered to the society (Husted, 2015). Today, the concept of CSR involves numerous corporate activities, such as: employee rights, natural environment protection, human rights, health protection, local communities' development, or the development of Third World countries (Jenkins, 2005).

Social responsibility, as a concept in management sciences, exhibited for the purposes of today's business, is gaining popularity also in practical terms, regardless of the disputes about its actual role in business (Kuźbik, 2016). According to S.P. Sethi (1975), an organisation considering responsibility may act in three ways, which are: social duty, social responsibility and social sensitivity. According to this distinction of attitudes towards responsibility, organisations must first meet the precondition, which is operation that complies with the law and market requirements. In other words, they must follow the law and provide added value to the environment in general. An organisation is socially-responsible if it meets the precondition, and simultaneously, respects common standards, values or social expectations towards its existence. The highest level of responsibility, according to Sethi, is social sensitivity. At this level, an organisation is ready to actively participate in social problem-solving or concentrate on the needs of a given society.

In 1971, Ph. Kotler and G. Zaltman used the term „social marketing” in reference to solving general social problems via commercial marketing tools (Wieczorkowska, 2003). At the same time, M. Friedman (1970) took a rather different approach, claiming that "the only corporate social responsibility is towards shareholders, CSR activities should not take place as they lower a company's profits." Today, it seems that the discussed concept is most frequently identified with the approach represented by the European Commission, which defines CSR as „a company's voluntary consideration of social and ecologic aspects while conducting commerce and contacting stakeholders" (Krukowska, 2015). 
Despite differences in the interpretation of the CSR concept, one aspect should be agreed upon - a company that plans on implementing activities from this area should be aware that it faces a challenge because it is a path from which there is no return. In a situation where a company wishes to back out of CSR activities, it opens itself up to negative comments on the side of clients, damaging its image and credibility in the eyes of market co-operatives.

\section{The Relationship between CSR and Marketing Communication}

Ph. Kotler defines marketing communication as „various ways in which companies attempt to inform and convince consumers as well as remind them - directly or indirectly - about their products and brands which they offer. In a sense, marketing communication is the voice of a company and its brands; a way, in which a company may establish a dialog and develop relations with consumers" (Kotler, Keller, 2012). Analysing the quoted definition of marketing communication and earlier definitions of CSR, it could be assumed that corporate social responsibility is inscribed in the communication trend described above. However, marketing communication (traditionally speaking) is made up of several tools: advertisements, sales promotion, public relations, direct marketing and personal sales. Looking through the lens of individual tools' specification, it appears that CSR shares the most features with public relations.

Practically speaking, public relations is about the creation and development of good contacts with the environment via communication. This process is defined by mutual social interactions via communiques that are aimed at mutual understanding of specific contents, which influences the opinion and approach of the audience towards the issued communiques. Therefore, „public relations is a process of communication between an organisation and its surrounding which is to achieve planned objectives while using appropriately selected means and methods" (Piasta, 1996). As such, public relations may be understood as a complex of specifically organised activities which ensure that a company systematically communicates with its surrounding, and aim at provoking desirable approaches and activities (Gasparski, Rutkowski, Wrzosek, 1992), for instance, creating an image of a socially-responsible company through activities performed in this area.

The relations between corporate social responsibility and public relations have not been entirely examined, which leaves room for questions and controversies. For some marketers, CSR is one of PR's tools. Others believe that CSR should be a distinctive form of activity. It should be noted that in many cases, the areas of CSR and public relations overlap. CSR is often viewed with suspicion - not as a genuine need to help others, but only a means to creating a positive image. Therefore, public relations should be the main communication tool for the CSR programmes. It is worth remembering that PR's mission should not be proving that helping is a company's fundamental value and making profit is only a side effect (Okoń, 2009).

In defined strategies for social engagement the following support forms can be considered: donating products or services; employee volunteer work; financial support (e.g. patronage, sponsorship); using a company's influence on the environment; social engagement marketing campaigns (e.g. Share Your Meal); sharing an office/space; purchases on local markets. The cooperation mechanisms include: corporate foundations (e.g. PKO BP Foundation); programmes supported by a corporate trademark (e.g. "Grasz o staż" - play for an internship); companies' and NGO's strategic partnerships (e.g. the financial service of the Great Orchestra of Christmas Charity by Bank Pekao); company coalitions that combine social activities with a brand's interests and/or companies' profits (e.g. „Nie robisz tego w realu? Nie rób tego w sieci!" - if you don't do it in real life, don't do it on-line - mBank's campaign to protect against cybercriminals); local inter-sectorial coalitions (Greszta, Kozakiewicz, 2009). All the above-mentioned 
activities may be used in communication operations in the area of a company's public relations. Some of them may be treated primarily as PR tools (e.g. patronage and sponsorship) and not CSR.

Surely, an increased role of CSR in the activity of the financial sector companies will raise more questions about its role in an organisation. Regardless of the position towards public relations, there is no doubt that social engagement activity intensifies PR's effects. The advantages of CSR in the area of corporate activity include, among others: the creation of a company's positive image; legitimising a company's mission in the eyes of clients, suppliers, cooperatives, etc.; gaining, or maintaining trust and loyalty of both current and potential clients; gaining local community's acceptance; contribution to improving internal situation in a company (e.g. increased satisfaction and happiness of employees, or an increase in their loyalty and willingness to identify with the company).

\section{Research Methodology - Analysis of the Contents of Wehsittes}

According to the data of the KNF - Financial Supervision Authority (2018), at the end of the year 2017, 35 commercial banks and 533 cooperative banks operated in Poland. According to data published by GUS - Central Statistical Office (2017) at the end of the year 2016, the licence to conduct insurance business had 62 insurance companies, out of which 61 establishments were operating.

Due to the volume restraints, only the scope of using csr by the largest companies in the financial services sector has been verified for the purposes of this study. It analyzes the contents of websites of the companies from the compilation of "Lista 500," the largest Polish enterprises published by „Rzeczpospolita” daily in April 2017 (the entities whose PKD classification - Polish Statistical Classification of Economic Activities - was specified predominantly as: financial and insurance activity, were selected). This particular ranking was employed as it is mostly large companies that pioneer the implementation of CSR activities and have adequate resources to conduct pro-social, large-scale operations. A total of 48 entities from the financial industry have been classified, including 20 banks, 25 insurance companies, and 3 companies engaged in a different kind of financial activity (on-line currency exchange office, short-term loans, leasing and managing company car fleet). Further analysis focused on 10 top entities from the first two groups, and all the others.

An audit of the contents of the websites was divided into 5 areas which verified:

1. Does the website present the company's mission, vision and values? If one of the elements was present, it was analysed whether its content included references to the role of social responsibility in everyday operations of a given entity (e.g. a fragment of PKO BP's mission: „We wish to continue having a positive influence on Poland - the people, companies, culture and natural environment. As one of the largest banks in Central and Eastern Europe, we handle responsibly the interests of our shareholders, clients, employees and local communities").

2. Does the company have a corporate foundation and does it provide information about it on its website?

3. Where can information on potential CSR be found in the layout of the website? Is it contained in a separate tab on the website's menu or is it a direct link dedicated to the website's CSR content (e.g. corporate foundation)? Is the information on CSR located in the website's section devoted to news and/or pressroom?

4. Does the given entity publish information about CSR in other places on-line that are hyperlinked on the company website, e.g. profiles on social media, hyperlinked pages of social campaigns, etc.?

5. Does the company publish up-to-date social reports (not older than two years)? 


\section{Communication about Social Engagement of the Companies of the Financial Services Sector via Websites - Analysis Results}

The conducted analysis illustrated that 14 out of 23 researched companies presented their mission, vision and values on their website (the details are found in Table 1). In 11 cases, their contents included a direct reference to corporate social responsibility. It is noteworthy that in two cases, despite a lack of reference to CSR in the mission, vision or values, it could be found in other places. In the case of Millenium Bank, the tab devoted to CSR included a position „influence of Millenium Bank on the society and natural environment”. On the other hand, Bank

Table 1. Communication about Social Engagement of the Companies of the Financial Sector via Websites

\begin{tabular}{|c|c|c|c|c|c|c|c|c|c|c|}
\hline \multirow[b]{2}{*}{ No. } & \multirow{2}{*}{ 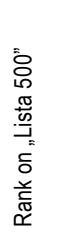 } & \multirow{2}{*}{ 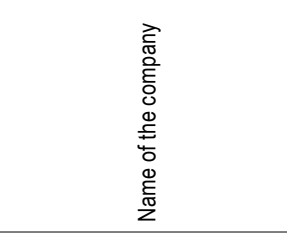 } & \multirow{2}{*}{ 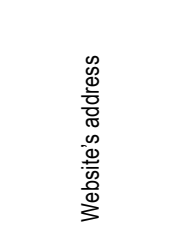 } & \multirow{2}{*}{ 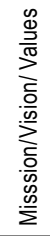 } & \multirow{2}{*}{ 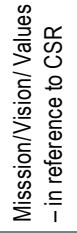 } & \multirow{2}{*}{ 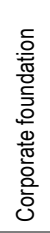 } & \multicolumn{2}{|c|}{$\begin{array}{l}\text { Placement of the information } \\
\text { about CSR on the website }\end{array}$} & \multirow{2}{*}{ 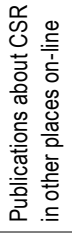 } & \multirow[b]{2}{*}{ 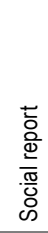 } \\
\hline & & & & & & & $\begin{array}{l}\text { CSR - a tab } \\
\text { on the website } \\
\text { or a link to the } \\
\text { foundation }\end{array}$ & $\begin{array}{l}\text { CSR in the } \\
\text { news and/or } \\
\text { pressroom }\end{array}$ & & \\
\hline \multicolumn{11}{|c|}{ Banks } \\
\hline 1 & 13 & PKO BP & pkobp.pl & yes & yes & yes & yes & yes & yes & yes \\
\hline 2 & 34 & BZ WBK & bzwbk.pl & yes & yes & yes & yes & yes & yes & yes \\
\hline 3 & 38 & Bank Pekao & pekao.com.pl & yes & yes & yes & yes & yes & yes & yes \\
\hline 4 & 61 & mBank & mbank.pl & yes & yes & yes & yes & yes & yes & yes \\
\hline 5 & 63 & ING Bank Śląski & ingbank.pl & yes & yes & yes & yes & yes & yes & yes \\
\hline 6 & 92 & Alior Bank & aliorbank.pl & - & - & - & - & yes & yes & - \\
\hline 7 & 94 & Bank Millenium & bankmillenium.pl & yes & - & yes & yes & yes & yes & yes \\
\hline 8 & 106 & Getin Noble Bank & gnb.pl & - & - & yes & yes & yes & - & - \\
\hline 9 & 108 & Bank BGŻ BNP Paribas & bgzbnpparibas.pl & yes & yes & yes & yes & yes & yes & yes \\
\hline 10 & 142 & Bank Handlowy w Warszawie & citibank.pl & yes & - & yes & yes & yes & yes & yes \\
\hline \multicolumn{4}{|c|}{ A total of "yes" for banks } & 8 & 6 & 9 & 9 & 10 & 9 & 8 \\
\hline \multicolumn{11}{|c|}{ Insurance companies } \\
\hline 1 & 5 & PZU & pzu.pl & - & - & yes & yes & yes & yes & yes \\
\hline 2 & 60 & Grupa Warta & warta.pl & - & - & - & - & - & - & - \\
\hline 3 & 62 & Grupa Ergo Hestia & ergohestia.pl & - & - & yes & yes & yes & yes & yes \\
\hline 4 & 169 & Aviva TUnŻ & aviva.pl & - & - & yes & yes & yes & yes & - \\
\hline 5 & 179 & Open Life TUŻ & openlife.pl & - & - & - & yes & yes & - & - \\
\hline 6 & 184 & TUiR Allianz Polska & allianz.pl & - & - & - & yes & yes & yes & - \\
\hline 7 & 186 & MetLife TUnŻiR & metlife.pl & yes & yes & - & yes & yes & yes & - \\
\hline 8 & 222 & Generali TU & generali.pl & yes & yes & - & - & yes & - & - \\
\hline 9 & 230 & Nationale-Nederlanden TUnŻ & nn.pl & yes & yes & - & - & yes & - & - \\
\hline 10 & 251 & TUnŻ Compensa & compensa.pl & yes & - & - & - & yes & yes & - \\
\hline \multicolumn{4}{|c|}{ A total of "yes" for insurance companies } & 4 & 3 & 3 & 6 & 9 & 6 & 2 \\
\hline \multicolumn{11}{|c|}{ Other financial activity } \\
\hline 1 & 11 & Cinkciarz.pl & cinkciarz.pl & yes & yes & - & yes & yes & yes & - \\
\hline 2 & 220 & Provident Polska & provident.pl & yes & yes & - & yes & yes & yes & yes \\
\hline 3 & 450 & Prime Car Management & primecar.pl & - & - & - & - & - & - & - \\
\hline \multicolumn{4}{|c|}{ A total of "yes" for other entities } & 2 & 2 & 0 & 2 & 2 & 2 & 1 \\
\hline \multicolumn{4}{|c|}{ A total of "yes" for all entities } & 14 & 11 & 12 & 17 & 21 & 17 & 11 \\
\hline
\end{tabular}

Source: own work. 
Handlowy in Warsaw had its reference to CSR in the tab "the rules of conducting the sponsorship programme" of the following content: "the bank conducts a sponsorship programme which constitutes an element of its business mission", however, a similar indication could not be found in the mission itself.

Among the researched institutions, 12 conducted their own foundation. In the case of ING Bank Ślaski, there were two: Foundation ING for Children and Foundation ING for Polish Art, which suggested the scope of their activity in their names. Thus, it can be concluded that the researched financial institutions communicated via their websites about 12 conducted corporate foundations.

In terms of the place of the information about CSR activities on the website, in 17 cases they were separate, dedicated subpages that were named differently in the menu of the page (foundation, CSR, social responsibility, sponsorship, patronage, etc.). In some cases, there were more subpages devoted to pro-social activities. For instance, on the main page, BZ WBK had 4 visible links to social activity: Foundation BZ WBK, Sponsorship, Responsible business, and Santander Universidades. The last element is an interesting programme supporting university education and research programmes. In 21 cases, the information about CSR activities appeared in various sections of the company website, most frequently in the news and/or pressroom (the section dedicated primarily to journalists).

Another analysed area, that is the publication of CSR information in other places on-line which was hyperlinked on the company website, was an element that was evaluated positively in 17 cases. Most often, the information about social engagement was communicated via social media profiles (mainly Facebook) and/or company blogs. The last verified activity established that 11 entities published their own social report (at times related to the report on the corporate foundation's activity), most often in the form of a downloadable file.

The analysis of CSR activities communicated via company websites, faired interestingly when 10 banks were compared with 10 insurance companies. In each area, banks had more notes confirming a given activity. 8 banks and 4 insurance companies provided information about their mission, vision or values on their website. 9 banks conducted their own corporate foundation, about which they communicated on their website. In contrast, only 3 foundations were conducted by insurance companies. Also, 9 banks had a tab (or several tabs) in the layout of the menu that was dedicated to social responsibility, compared with 6 insurers. An identical numerical structure recurred in the case of publishing information about CSR in other places on-line, which were hyperlinked on the company website. The last area - publishing social reports, as before, was in favour of banks in the ratio 8 to 2 .

\section{Conclusions}

An increased pressure put on companies to elicit socially responsible behaviour illustrates the changing role of economic entities in our society. CSR as a concept should be understood and analysed as a function of numerous socio-economic and political processes, such as: technological progress, globalisation, liberalisation of the trade, growing pressure and expectations of the media and consumers as well as the emergence of CSR promoting instruments

Following the observation of the largest companies of the financial services sector on the Polish market, it can be concluded that the idea of social responsibility is gaining influence on the creation of brands. However, there are still a number of defects in the way CSR activities are communicated and the activity itself at times does not seem well thought-through or cohesive with the rest of the company's marketing communication strategy. Based on this, it can be concluded that CSR is still an area that needs improvement among the companies of the financial 
services sector. The comparison of banks with insurance companies (in favour of the latter) surprisingly shows how diverse communication about social engagement can be, considering the numerous capital interconnections between both kinds of institutions. CSR is an opportunity to build a positive, distinctive image, prove that the policy is coherent and clear to the recipients and that it is appropriately supported by the activities from the area of marketing communication, including public relations. Conducting CSR in this manner offers an edge over competition because recipients start associating a given company with a decent citizen.

\section{References}

Carroll, A.B. (1999). Corporate social responsibility evolution od a definitional construct. Business\&Society, 38 (3), 268-295.

Friedman, M. (1970). The Social Responsibility of Business is to Increase Its Profits. The New York Times Magazine, September 13 , 32-33.

Gasparski, L., Rutkowski, I., Wrzosek, W. (1992). Marketing. Punkt zwrotny nowoczesnej firmy. Warszawa: PWE.

Gontarczyk, K. (2003). Firma prospołeczna. Marketing w praktyce, 1 (59), $26-28$.

Greszta, M., Kozakiewicz, M. (2009). Indeks BI-NGO 2009. Komunikowanie o społecznym zaangażowaniu firm w Internecie. Instrukcje dla badaczy. Instytut Partnerstwa Biznesu i Organizacji Pozarządowych BI_NGO.

Husted, B.W. (2015). Corporate Social Responsibility Practice from 1800-1914: Past Initiatives and Current Debates. Business Ethics Quarterly, 1 (25), 125-141.

Jenkins, R. (2005). Globalization, corporate social responsibility and poverty. International Affairs, 81 (3), 525-540.

Kotler, Ph., Keller, K.L. (2012). Marketing. Poznań: Rebis.

Krukowska, M. (2011). Definicje i standardy CSR. Retrieved from: http://www.forbes.pl/artykuly/sekcje/baza-wiedzy-csr/definicje-istandardy-csr,3879,1 (4.04.2017).

Kuźbik, P. (2016). Społeczna odpowiedzialność w przestrzeni organizacyjnej klubu piłkarskiego. Łódź: Wydawnictwo SIZ.

Okoń, M. (2009). Związek między PR a CSR. Gazeta Finansowa, September 18, 23.

Piasta, Ł. (1996). Public relations. Istota techniki. Warszawa: Centrum Informacji Menedżera.

Sethi, S.P. (1975). Dimensions of Corporate Social Performance. An Analytic Framework. California Management Review, 17 (3), 58-64.

Wieczorkowska, M. (2006). Elementy marketingu społecznego i ich zastosowanie w kampanii antynikotynowej Quit\&Win. Marketing i Rynek, 3, 24-30.

Woźniakowski, M. (2015). CSR jako narzędzie komunikacji marketingowej firm sektora TSL. Acta Universitatis Nicolai Copernici, Ekonomia, 2 (46), 195-203.

GUS (2017). Polish Insurance Market 2016. Retrieved from: https://stat.gov.pl/files/gfx/portalinformacyjny/pl/defaultaktualnosci/5503/ 11/7/1/polski-rynek-ubezpieczeniowy-2016.pdf (17.05.2018).

KNF (2018), Dane miesięczne sektora bankowego - grudzień 2017. Retrieved from: https://www.knf.gov.pl/?articleld=56224\&p_id=18 (17.05.2018).

Cite this article aS: Woźniakowski, M. (2018). CSR as a Marketing Communication Tool for Companies in the Financial Services Sector. European Journal of Service Management, 1 (25), 345-351. DOI: 10.18276/ejsm.2018.25-42. 